\title{
Approaches to building indices for the program-oriented development of settlements in the Ukrainian context
}

\author{
Maksym Filiak ${ }^{1 *}$; Juliia Filiak
}

1) Lviv University of Business and Law, Ukraine

${ }^{2)}$ Lviv National University of Veterinarian Medicine and Biotechnologies, Ukraine

*To whom correspondence should be addressed.Email: mfilyak@gmail.com

\begin{abstract}
:
The focus of this study is to present an overview of Ukrainian scientific approaches to the development of monitoring and evaluation technical components, namely matrices, models, indicators and indices used in implementation of program-oriented approach to socio-economic development of settlements. The article describes scientific developments from two main fields (economic development and social development) and is grounded on the authors' previous research, to describe the main types of groups indicators of sustainable socio-economic development for Ukrainian settlements. The need for the study is pertinent given the absence of uniformity to approaches and the need for the research to develop practically applicable monitoring tools for the research.
\end{abstract}

Keywords: harmonization indicator, program-oriented approach, strategic planning, labor resources

JEL Classification: O18,O35, O38, R28

\section{INTRODUCTION}

The recent development in program-oriented approach focus on two main fields: economic development of productive municipal systems, and social development and the movement of productive forces within the settlement. Sustainable development is sometimes seen as a linkage to these two fields. Recent studies have formulated a number of sustainable -development indicators or markers to be used to monitor harmonization in implementation of socio-economic development strategies; however, the existing indices largely omit the issue of relations between the urban and rural parts of a territorial cluster; and do not take into account the aspect of movement of labor resources. The current study presents an evolution of these indexes where the indicated gaps have been partially filled.

A number of international research have focused on the indicators in the settlement development strategies. A study by Owen (2011) has investigated deeper on such factors as lacunarity and degree of vegetation in various types of settlements, in correlation with the indicators of quality of life and status in regional economics. Linard, Gilbert, Snow, et al. (2012) have produced a study outlining research findings that linked together correlations of dispersity, patterns of settlements and accessibility conditions in Africa. Ismail and Gado (2013) have outlined some of the indicators of sustainable development of territorial settlements. A study by Kamran (2015) focused on identifying factors of influence on the quality of life indicators in the suburban residential areas near Islamabad. 
Fitzgerald et al. (2015) have researched how a settlements sustainable development plans and policies can be monitored against the baseline; and have provided groups of socioeconomic indicators applicable to the settlements of Ireland. The current study is a complementing input into the system of knowledge on such indicators, which makes extensive use of the Ukrainian context and present some evolution as to grouping of indices.

\section{REVIEW OF LITERATURE AND EVOLUTION OF DISCOURSE}

As to the first field of research (economic development of productive systems in a city in the Ukrainian context), the following research can provide a deeper insight into the object of study.

Nikiforov and Babukh (2015) explore aspects of financial provision for the economic development of urban settlements. They devote considerable attention to the practical issues of financial support and the updating of the concepts of such development in the system of self-government in Ukraine. The authors propose a system for analyzing the revenue and expenditure parts of the city budget, as well as presenting the results of the assessment of the efficiency of budgeting in the territorial communities. In general, the analysis was carried out in the framework of fiscal decentralization. Considerable attention is paid to new opportunities for improvement of financing of the municipal development, which arose due to changes in the legislation of Ukraine. The authors propose a system for measuring, controlling and streamlining urban development in the financial aspect. In particular, a model of influence of financial development instruments and socio-economic development on individual cities of the region on the basis of professors' achievements was created based on the research of Harazishvili (2007). In contrast to traditional models that use correlation-regression analysis and are based on the approximation and simplification of past trends for predicting the future, this model uses methods of economic cybernetics and a systematic approach. Based on Keynesian and monetarist approaches, using the macroeconomic indicators, an index was created that determines the growth of gross value added (GVA) as a change in nominal and real value added. Subsequently, interpretations and calculations were carried out based on the model of the consolidated economic equilibrium.

Vyshyvanyuk (2012) in his monograph examines the challenges that arise during the regulation of the development of the socio-economic component of a small city, using the example in the Western region of Ukraine. The author determines the place of such urban development in the wider social system of the region. Acknowledging the processes of irreversible transformation of small cities, the author identifies the main ways of resource utilization, including the productive forces of such cities, especially against the backdrop of the reform of the administrative-territorial system and the formation of the communal property institute in the communities. The author has developed a model of an economic diagnosis of measures aimed at providing small towns with social services through the assessment of the implementation of relevant standards. The model is presented in the context of municipal strategic planning, which is part of a programoriented approach. The author operates several determinants - that are regulators of the development of a small city, and the analysis of which is offered. The model proposed by the author is based on a systematic approach that propagates the unity of administrative, spatial planning and effective budgeting processes. The detailed interpretation of the 
feasibility of the main points of implementation of the socio-economic development strategy of is presented.

O. Berdanova, V. Vakulenko, I. Valentyuk (2011) offer a comprehensive approach to urban planning. Links of spatial planning systems, as well as systems of strategic and operational planning of socio-economic development of settlements that are part of a program-oriented approach have been studied. Unlike some other works, more attention is paid to operational planning when implementing development strategies. The authors also emphasize the practical need for monitoring, which needs to be improved in practice for use in strategic planning of self-government bodies. The authors developed a model in the form of a program-oriented approach in the context of urban land management. The choice of the scope is due to the increase in recent years of the level of investment attractiveness of the land resources of Ukrainian cities, especially the large ones. The authors view these resources as a spatial basis for urban development. The model is presented in a strategic analysis format with key recommendations. The authors operate the key determinants of the effectiveness of such a strategy and place a significant part of its implementation on the bodies of the city authorities as subjects of land relations.

Yatsyshyn (2013) explored the development of urban settlements in the context of globalization. The author focuses on the impact of globalization on aspects of socioeconomic development, studied within the framework of a program-oriented approach. The author carried out a factor analysis of the main globalization challenges faced by a large city. In this context, the author created analytical clusters or structural-logical models that represent chains of resources, factors and results, and are characteristic of a program-oriented approach.

For each of the clusters, a statistical analysis was carried out and key conclusions were drawn on the example of a major regional city (Lviv). Similar to the research within the POA framework, the author identifies the strengths and weaknesses of the construction and practical implementation of the strategies of the territorial community and the city. To overcome the disadvantages of planning mentioned in the work, the author proposes three types of mechanisms within the framework of the approach, which is quite in accordance with the use of the sets of tools for POA.

Kalashnikova (2013) exacerbated attention to the development of a large city. According to the author, in a big city, strategic development, provoked, possibly, as a reaction to the economic decline of the past decades, should become a priority. The author highlights the principles of effective strategies, among which are: adaptability, consideration of factors of influence of external forces, grounding on existing traditions, and modernization of approaches based on technologies. The author examines these processes at the intersection of the system, institutions, and using the convergence principles.

The author proposes a systematic approach that contains several tens of partial and several complex indexes (integral indicators) built based on simple socio-economic development indicators. In particular, the author identifies indicators of stimulants (push variables) and indicators of de-stimulants (limiting variables) for the definition of strategic steps. The example of Kharkiv (a major regional city) shows the dynamics of changes in these complex indices.

Kolodych (2012) explores the influence of the factors of sustainable development and the social component on urban development. The author believes that the system of development management at the level of the municipal authorities should integrate 
subsystems of management of living standards and well-being of the population, which are productive forces and development tools for settlements, and which are also widely studied as part of the program-oriented approach. The author creates a scientific basis for the implementation of elements of social policy at the local level. She builds a logicalstructural matrix, which integrates social factors and is based on causation analysis. Operating many indicators of municipal socio-economic development, the author proposes to use a formula that shows which indicators - positive or negative - prevail in social policy. This formula is supported by the scheme to apply a broader approach to strategic development.

Nazaruk (2010) explored the geographical, constructive and environmental subsystems of urban settlement development, analysis of which is also inherent in the POA through the system of indices. The author will build a study on examples of urban areas and identify priorities for their transformation in terms of the speed of the processes of change. According to the author, urbanization affects the relations of society and nature, and this factor should be considered in strategic planning. The author investigates the cycles of the city development, identifies determinants and regulators by analyzing the city's system in the light of geographical and constructive factors and nets, and formulates recommendations for improving the use of nature in conditions of rapid urbanization. The pendulum migration of labor resources as a factor of social load on the example of the major regional city is investigated, which is associated with an increase in the technogenic load on natural systems and the environment.

Challenges faced by social development and movement of productive forces within the settlement, namely indices and systems of movement of productive forces, is a closely related field of study, directly developing the instrumental side of program-oriented approach, including in the context of movement of labor and migration resources.

Matviishyn (2011) considers the place of the human capital management system and labor resources, including migrants, as part of the regional development strategy. The author describes plans and algorithms for workflow optimization in the management of labor resources within the context of the development of the region and the organization. According to the author's concept, the human resources management, regardless of their origin, should contribute to improving the quality of human capital of the organization and the region. Thus, the author relates the movement of labor resources directly with the development of the territory but sets the quality of strategic management as a predeterminant of the growth of welfare of the organization and the region. Thus, according to the author, strategic management is the key to the positive impact of human resources on the development of the territory. According to the author, the strategic integration of tasks from the socio-economic development of the territory with plans for the development of human capital is one of the key objectives of human resources management.

Olshevska (2007) deals more closely with the issue of the movement of human resources across borders as a phenomenon characteristic of the twentieth century, in the context of the threats and challenges of socio-economic development of regions and countries of the world. The author suggests that high-quality human resources are a determinant of the international competitiveness of those states that have moved to a large extent into the post-industrial economy. The author closely relates the movement of human resources and the strategy or policy of its regulation, while distinguishing two types of such documents, namely macroeconomic policies and social policies, which 
equally affect the phenomenon of migration. The author agrees that the study of the impact of migration resources and socio-economic development of the territory has been highly relevant for Ukraine, but she studies these interdependencies in the normal socioeconomic development scenario rather than in the crisis context. At one time, the author substantiated the necessity of introducing protectionist policies and restraining on migration of labor resources abroad, as the negative impact on Ukraine's international competitiveness was revealed.

Karpenko (2010) defines the state of development of rural areas in Ukraine as a protracted, long-term crisis and proposes to introduce a comprehensive approach to their restoration, including using the tools of sustainable development. The author identifies the impoverishment of the population as one of the factors of the territory's crisis. Sustainable development is closely linked to the harmonization of productive forces and is seen it as a way out of the crisis, a sign of such progress is the satisfaction of the necessary needs of all members of society. Thus, the author further emphasizes the need to increase the degree of organization of the socio-economic system as a factor for sustainable development, which helps in overcoming the crisis.

Yarotskiy (2011) has studied a complex of indicators of labor resources and the key factor which is employment. The author identifies a clear link between economic crises and the growth of domestic unemployment on the one hand, and worsening welfare of labor and uncontrolled migration (outflow) abroad - on the other hand. According to the author, the negative effect of these phenomena is the deterioration of the quality of labor resources and the reduction of the reproducibility of the workforce. The author stresses the necessity of a comprehensive assessment of the identified links and allocates the economically active population as the main subject of the study of labor resources and the marker modification in the evolution of these resources.

Yakovenko and Rosenko (2011) examine the structure and constituent factors of human capital, which has a close correlation with labor resources. Acknowledging the complications in the development of human capital in Ukraine, the authors suggest ways to overcome them. At the same time, they determine the quality of human capital as one of the factors of the competitiveness of the territory and its enterprises. In the work, great importance is devoted to investment strategies in the development of human capital if it is recognized among the most valuable resources of the territory the state. The authors define such investment as a method of accumulation of high-quality human capital against the background of its occasional outflow.

Reshetylo, Mischenko and Shubna (2014) explore performance factors of spatial allocation of human resources and their effective use. According to the authors, allocation of human resources, which has a direct connection with migration is one of the key factors of the spatial asymmetry. The authors consider the concept of human capital, assigning it the characteristics of the quality of labor resources. The authors also explore the relationship of the placement of human resources and human capital as their characteristics depending on the key indicators of economic growth in the region.

Burmaka and Burmaka (2011) explore practical issues of human capital management of an enterprise and attribute the development of the enterprise to the motivation of its employees. Thus, methodological point of view, the research leads to a thesis on the motivation of labor resources, which has an attachment to the economic object and source of workplaces, and which (motivation) is considered as a key factor in the territorial loyalty of labor resources, especially their employed part. The authors 
emphasize the need for the development of motivation for workers, including the managers and innovators at an enterprise.

Aleksandrov (2012) investigated the factors of human capital quality in Ukraine, and offers ways to improve, substantiating the positive impact of human capital growth on the economic indicators of the economy. The author believes that the parameters of social freedom, responsibility and legal awareness, among others, are the ones that determine the features of a good worker, and at the same time serve as markers of the most productive and thus valuable employees. These parameters of the quality of human capital also affect the migration of the population and the formation of the labor market both inside the country and abroad.

Kravchenko (2015) combines the principles of social policy and the principles of development of rural communities in Ukraine. The author considers it appropriate to intensify the development of the village, and for this purpose, firstly, the role of the state in the development of the village through social policy should be increased, and secondly, the level of participation of citizens (labor resources) in the decision-making processes in the countryside should be enhanced. Thus, the author highlights two important factors that hamper the development of human resources in rural areas of Ukraine.

Petrushenko (2014), while continuing the broad research in community development, considers aspects and the structure of the financial policy of the development of territorial communities, with a special emphasis on local development. According to the author, civil society as a motive for citizens participation at the level of the local rural community is one of the key players in the policy of increasing the production of common local public goods in Ukraine. The author considers the involvement of the population to participate in the formation of financial policy at the local level as a significant factor in the growth of the quality of human capital of the territorial communities of the country.

Romanenko (2015) presented the statistical measurement of Ukrainian labor migration. In her work, the author defined the means of studying the migration of labor resources as a structural phenomenon, recommended a system of indicators for statistical study of the structure of migration, and also assessed the dynamics of migration of the population of Ukraine and their financial resources.

\section{METHODS}

The study analyzed the 2015-2018 data in the indicated fields of research to develop indices suitable for practical use. The following is a deeper research on the composition, scheme and variables of several major groups of indices which have been identified as important markers of successful socio-economic development of a territorial cluster, where large cities have socio-economic interactions with the rural areas.

The research was aimed at: developing groups of quality complex indicators (indices) which will allow to assess the stage of strategic development of a settlement or amalgamated community in various functional fields, as a linkage between long-term and project planning systems.

Research hypothesis stated that most of indicators used in real, field strategies are out of date and cannot objectively assess strategic development. Also, most indicators can be improved and grouped into indices, which can be further improved based on the existing theoretical research. Asa consequence, these indices will from a structural block in a logical structure of program-oriented approach to socioeconomic development of 
settlements, which, most importantly, should emerge as a linkage between long-term forecasting and project-level and operational management at a settlement level.

Inn terms of the methods, as the research was developed by 2 authors, a part of the research originated from studies of migration and labor resources of the same period, which appeared relevant for this field of study. The study used desk research as well as empirical research of the documents used in practice. The desk research developed argumentation based on existing and known socioeconomic trends for Ukraine and developed elements of some indices (12 separate findings produced in total). The empirical component relied of analysis of the existing strategic -level plans and analytic reviews related to amalgamated communities.

Research procedure, specifically, included empirical analysis of groups of strategic documents that were developed in 2 eastern regions of Ukraine during 2015-2018, namely: 7 Strategies for socioeconomic development of amalgamated territorial communities; 7 Organizational development plans of amalgamated territorial communities; 7 Analyses of socio-economic development of amalgamated territorial communities; 4 monitoring and evaluation plans of socioeconomic development strategies, 20 Evaluation surveys of capacity assessment of management of amalgamated territorial communities, and 10 Financial profiles of amalgamated territorial communities. These documents were proportionally dispersed in 2 research regions where administrative reform was ongoing. Based on the existing approaches to building indicators, the existing indicators from the documents were analyzed against the factors of composition and grouped. Some additional recommendations were provided, related to various types of indices that accompany the respective strategic documents.

\section{RESULTS AND DISCUSSION}

The basic description of indices was taken from the authors' previous studies (see, for example, Filyak and Zavadovska (2016); Zavadovska and Filyak (2016); Filiak (2018) as well as Zavadovska (2016), and they have been further developed and specified below. All groups of indices are a part of the program-oriented approach to economic development of settlements and are to be used in complex assessments of efficiency of strategy implementation. The indices are designed to be employed to assess progress of development of Ukraine's amalgamated territorial communities (hromadas) which currently undergo a decentralization reform; but can be also used to municipal and rural territorial entities in other regions.

Table 1. Grouping of principal indices for strategic assessment of an amalgamated community

\begin{tabular}{|l|l|l|l|}
\hline $\begin{array}{l}\text { Main groups of } \\
\text { indices }\end{array}$ & $\begin{array}{l}\text { Types of index } \\
\text { composition and } \\
\text { methods of } \\
\text { calculation }\end{array}$ & $\begin{array}{l}\text { Purpose and ways } \\
\text { of practical use }\end{array}$ & $\begin{array}{l}\text { Objects/data to } \\
\text { analyses for } \\
\text { calculation of } \\
\text { variables }\end{array}$ \\
\hline General & $\begin{array}{l}\text { 4 or 5 principal } \\
\text { multifactor indices, } \\
\text { with variables } \\
\text { composed of 1 } \\
\text { socioeconomic } \\
\text { dependency, and } \\
\text { graded at max and } \\
\text { min. }\end{array}$ & $\begin{array}{l}\text { Provide general } \\
\text { understanding of the } \\
\text { settlement's potential } \\
\text { for development and } \\
\text { clarify the necessity } \\
\text { for further } \\
\text { evaluations. Assess } \\
\text { settlement's long- } \\
\text { term prospects. }\end{array}$ & $\begin{array}{l}\text { Data gathered by } \\
\text { and interviews with } \\
\text { key staff and major } \\
\text { informants of a } \\
\text { settlement }\end{array}$ \\
\hline
\end{tabular}




\begin{tabular}{|c|c|c|c|}
\hline $\begin{array}{l}\text { Main groups of } \\
\text { indices }\end{array}$ & $\begin{array}{l}\text { Types of index } \\
\text { composition and } \\
\text { methods of } \\
\text { calculation }\end{array}$ & $\begin{array}{l}\text { Purpose and ways } \\
\text { of practical use }\end{array}$ & $\begin{array}{l}\text { Objects/data to } \\
\text { analyses for } \\
\text { calculation of } \\
\text { variables }\end{array}$ \\
\hline $\begin{array}{l}\text { Socioeconomic } \\
\text { development -related }\end{array}$ & $\begin{array}{l}\text { Variables formed as } \\
\text { correlations of } \\
\text { generalized major } \\
\text { features of model } \\
\text { socioeconomic } \\
\text { development plans. } \\
\text { Variables grouped } \\
\text { into indices by } \\
\text { strategic directions. }\end{array}$ & $\begin{array}{l}\text { Assess progress and } \\
\text { challenges along } \\
\text { main venues of } \\
\text { implementation of a } \\
\text { settlement's 7-year } \\
\text { strategy. }\end{array}$ & $\begin{array}{l}\text { Strategies for } \\
\text { socioeconomic } \\
\text { development of } \\
\text { amalgamated } \\
\text { territorial } \\
\text { communities } \\
\text { (hromadas) }\end{array}$ \\
\hline $\begin{array}{l}\text { Organizational } \\
\text { development-related }\end{array}$ & $\begin{array}{l}\text { Variables formed as } \\
\text { generalized major } \\
\text { features of model } \\
\text { organizational } \\
\text { development plans. } \\
\text { Variables grouped } \\
\text { into indices by } \\
\text { planning directions. }\end{array}$ & $\begin{array}{l}\text { Assess progress and } \\
\text { challenges along } \\
\text { main venues of } \\
\text { implementation of a } \\
\text { settlement's 7-year } \\
\text { organizational } \\
\text { development plan. }\end{array}$ & $\begin{array}{l}\text { Organizational } \\
\text { development plans of } \\
\text { amalgamated } \\
\text { territorial } \\
\text { communities } \\
\text { (hromadas) }\end{array}$ \\
\hline Entropy-related & $\begin{array}{l}\text { Variables } \\
\text { representing the } \\
\text { weakest points of a } \\
\text { settlement's } \\
\text { socioeconomic } \\
\text { standing, grouped } \\
\text { into thematic indices } \\
\text { (up to } 6 \text { "diamond" } \\
\text { or "star" indices, } \\
\text { with up to } 9 \\
\text { variables each) }\end{array}$ & $\begin{array}{l}\text { Identify the degree of } \\
\text { influence of the } \\
\text { settlement's weakest } \\
\text { points on its strategic } \\
\text { development }\end{array}$ & $\begin{array}{l}\text { Analyses of socio- } \\
\text { economic } \\
\text { development of } \\
\text { amalgamated } \\
\text { territorial } \\
\text { communities } \\
\text { (hromadas) }\end{array}$ \\
\hline $\begin{array}{l}\text { Order of } \\
\text { management-related }\end{array}$ & $\begin{array}{l}\text { Variables } \\
\text { representing the } \\
\text { weakest points of a } \\
\text { settlement's } \\
\text { managerial capacity, } \\
\text { grouped into } \\
\text { thematic indices (up } \\
\text { to } 6 \text { "diamond" or } \\
\text { "star" indices, with } \\
\text { up to } 9 \text { variables } \\
\text { each) }\end{array}$ & $\begin{array}{l}\text { Identify the baseline } \\
\text { and, further, assess } \\
\text { targets for the growth } \\
\text { of management } \\
\text { potential of a } \\
\text { settlement }\end{array}$ & $\begin{array}{l}\text { Evaluation surveys } \\
\text { of capacity } \\
\text { assessment of } \\
\text { management of } \\
\text { amalgamated } \\
\text { territorial } \\
\text { communities } \\
\text { (hromadas) }\end{array}$ \\
\hline $\begin{array}{l}\text { Financial } \\
\text { development - } \\
\text { related }\end{array}$ & $\begin{array}{l}\text { Indicators of budget } \\
\text { efficiency, grouped } \\
\text { into indexes by } \\
\text { thematic areas of a } \\
\text { financial profile. } \\
\text { Sometimes also } \\
\text { variables showing } \\
\text { major correlations of } \\
\text { budget efficiency. }\end{array}$ & $\begin{array}{l}\text { Identify the baseline } \\
\text { and, further, assess } \\
\text { targets for the growth } \\
\text { of financial } \\
\text { sustainability of a } \\
\text { settlement }\end{array}$ & $\begin{array}{l}\text { Financial profiles of } \\
\text { amalgamated } \\
\text { territorial } \\
\text { communities } \\
\text { (hromadas) }\end{array}$ \\
\hline
\end{tabular}




\begin{tabular}{|l|l|l|l|}
\hline $\begin{array}{l}\text { Main groups of } \\
\text { indices }\end{array}$ & $\begin{array}{l}\text { Types of index } \\
\text { composition and } \\
\text { methods of } \\
\text { calculation }\end{array}$ & $\begin{array}{l}\text { Purpose and ways } \\
\text { of practical use }\end{array}$ & $\begin{array}{l}\text { Objects/data to } \\
\text { analyses for } \\
\text { calculation of } \\
\text { variables }\end{array}$ \\
\hline $\begin{array}{l}\text { Sustainable } \\
\text { development-related }\end{array}$ & $\begin{array}{l}\text { 2 groups of } \\
\text { variables, one } \\
\text { assessing the city's } \\
\text { influence on a } \\
\text { village, and another } \\
\text { assessing the } \\
\text { village's influence } \\
\text { on a city (within the } \\
\text { territorial cluster, or } \\
\text { amalgamated } \\
\text { community) }\end{array}$ & $\begin{array}{l}\text { Assess level of } \\
\text { harmonization in } \\
\text { implementation of } \\
\text { the settlement's } \\
\text { strategic documents } \\
\text { along the principles } \\
\text { of sustainable } \\
\text { development }\end{array}$ & $\begin{array}{l}\text { Sustainable } \\
\text { development } \\
\text { strategies and } \\
\text { operational plans of } \\
\text { amalgamated } \\
\text { territorial } \\
\text { communities } \\
\text { (hromadas) }\end{array}$ \\
\hline
\end{tabular}

Source: authors' research

\section{CONCLUSIONS AND RECOMMENDATIONS}

\section{Conclusions}

For complex assessments of progress of socio-economic development of settlements at strategic level, "diamond" or "star" indices could be used, formed by 6 to 9 variables each, with a minimum mark at Zero and maximum at Five. The Zero mark is called "the minimum margin" while the Five mark is called "the maximum margin". Usually the mark cannot fall below Zero and is rather unrealistic to rise beyond Five within the timing of a strategic document (7-8 years). The indices are used within the settlement's M\&E framework and their annual tracking allows to observe the dynamics of strategic development of a settlement against a pre-defined baselines and targets. The Entropy-related and Order of management-related indices differ because they assess the level of order vs. chaos in the settlement's strategic development and management order. The Sustainable development-related indices are peculiar as they are designed to assess how the major elements of a territorial cluster (including the major city and several villages) interact with each other.

\section{Recommendations}

Recommendations related to the composition of a harmonization index are: a) Have a variable to analyze the revenue and expenditure parts of the budget; b) Have a formula to assess results of evaluation of budgeting efficiency; c) Be built as a system of coordinates allowing to explore opportunities to improve funding; d) Enable assessment of the impact of instruments and financial development on the socio-economic; e) development of settlements, using a systems approach; f) Enable assessment of added value as a result of development, using economic equilibrium/harmonization models.

Recommendations related to the composition of a regulatory index are: a) Enable to recommend on the main ways of using resources, including productive forces of cities; b) Include a variable to assess measures of the provision of a small city with critical services; c) Enable the user to compare progress on various dimensions, e.g. administrative, spatial planning and effective budgeting; d) Include variables that show correlations among spatial planning systems, and systems of strategic and organizational planning of socio-economic development of the settlement; e) Include a set of markers to 
monitor at least the most critical areas of performance; f) Include a variable dedicated to cost of land as a resource related to a settlement; g) Enable the user to see correlations between land as an investment resource and the city's (hromada's) expansion potential.

Recommendations related to the composition of a balancing index are: a) Include a variable characterizing impact of major global challenges on a settlement; b) Use logic models and chain of resources, factors and results to correlations; c) Enable the user to notice strengths and weaknesses of a settlement's development plan, after analyzing the above correlations in dynamics; d) Include a variable to show dangers of falling into economic decline and offer grading to solutions like enforced growth; f) Include not too many simple socio-economic development variables, to facilitate understanding; g) Include a group of push variables and a group of limiting variables.

\section{REFERENCES:}

Alexandrov, D.V. (2012). Socio-psychological peculiarities of human resources in Ukraine. Problems of management of production and economic activity of business entities: Scientific Works VI International scientific conference of young scientists, April 19, 2012, DonNTU (Donetsk). 274 p.

Berdanova O. V., Vakulenko V. M., Valentyuk I. V. et al. (2011). Planning of social and economic development of the city. NAPA (Kyiv). $160 \mathrm{p}$.

Burmaka M.M., Burmaka T.M. (2011). Management of enterprise development on the example of enterprises of the construction industry).KhNADU (Kharkiv). 204 p.

Filiak, M.S. (2018). An overview of the determinants of the cluster system of settlements in accordance with the territorial spatial organization. Scientific studies of the Tavrisky national university n.a. Vernadsky, Series: Economics and Management.vol. 29 (68). 43-48

Filyak, M. S. and Zavadovska, Y. Y. (2016). A survey of results of efficiency of integration of internally displaced persons in the social structure of the host communities in the regions of Ukraine. Prychornomorski ekonomichni studii, vol. 7, 197-201.

Fitzgerald B.; O'Doherty T., Moles R. and O'Regan B. (2015). Quantitative Evaluation of Settlement Sustainability Policy (QESSP); Forward Planning for 26 Irish Settlements. Sustainability 2015, 7, 1819-1839; doi:10.3390/su7021819. https://www.mdpi.com/2071-1050/7/2/1819/pdf

Ismail, Ayman and Gado, Hisham. (2003). Sustainable Settlement Development Indicators. Conference: Arab Regional Conference on Improving Living Conditions Through Urban Sustainable Development, At Conrad Hotel- Cairo Egypt.

Kalashnikova H.I. (2013). Strategic directions of social and economic development of a large city: author's abstract. 08.00.05 - Dissertation for obtaining the scientific degree of the candidate of economic sciences. Cherkasy state technological university (Cherkasy). $253 \mathrm{p}$.

Kamran, Jalal (2015). Investigating the affecting factors on quality of life in informal settlements' neighborhoods, with an emphasis on the Islamabad neighborhood in Zanjan. Ciência eNatura, Santa Maria, v. 37 Part 1 2015, 286-297. https://periodicos.ufsm.br/cienciaenatura/article/.../20859/pdf

Karpenko V.V. (2010). Ratio of concepts of "sustainable" and "integrated" development of rural communities. Public administration: theory and practice. Electronic collection of scientific papers. Vol. 2 (4). 
Kharazishvili Yu.M. (2007).Theoretical fundamentals of system modeling of socioeconomic development of Ukraine. Polygraph Consulting Ltd. (Kyiv). 324 p.

Kolodich, E. V. (2012) Ensuring Sustainable Development of the Social Sphere of Modern Cities: author's abstract. 08.00.05-Dissertation for obtaining the scientific degree of the candidate of economic sciences. Cherkasy state technological university (Cherkasy). $20 \mathrm{p}$.

Kravchenko T.A. (2015). Development of the village with the help of village communities: innovations in public policy in Ukraine. Current problems of public administration. -. - Nr 1. - P. 87-95

Linard, C., Gilbert, M., Snow, R. W., Noor, A. M., \& Tatem, A. J. (2012). Population Distribution, Settlement Patterns and Accessibility across Africa in 2010. PLoS ONE, 7(2), e31743. http://doi.org/10.1371/journal.pone.0031743

Matviishyn E.G.(2011). Strategic Human Resource Management: A teaching manual.. NAPA (Kyiv) $222 \mathrm{p}$.

Nazaruk N. N.(2010). Structural and geographic bases of development and functioning of social-ecological systems of a large city: author's abstract. 11.00.11Dissertation for obtaining the scientific degree of the candidate of geographic sciences. I. Franko LNU (Lviv). 32 p.

Nikiforov P.O., Babukh I.B. (2015). Financial provision of social and economic development of cities. Chernivtsi: Technodruk,. - 204 p.

Olshevska I.P. (2007). International migration of human resources: author's abstract. 08.00.02 - Dissertation for obtaining the scientific degree of the candidate of economic sciences. Kyiv. 20 p.

Owen, K. (2011). Settlement indicators of wellbeing and economic status - lacunarity and vegetation. Conference: Pecora 18 -Forty Years of Earth Observation.Understanding a Changing World November $14-17,2011$, Herndon, Virginia. http://www.asprs.org/pecora18/proceedings/Owen.pdf

Petrushenko Yu. M.(2014). Socio-economic essence and financial self-sufficiency of territorial communities. Scientific herald of Chernivtsi university. Nr. 710-711. Economy. -: ChNU (Chernivtsi). 45-48.

Reshetylo V.P.(2014). Labor resources of the regions: spatial placement and increase of efficiency of use: monograph.Kharkiv National University. 157 p. ISBN 978-966695-322-6

Romanenko Iryna Aleksandrovna (2015). Statistical analysis of labor migration. Specialty 08.00.10 - Statistics. Dissertation for obtaining the scientific degree of the candidate of economic sciences. Kyiv. UDC 311.2: 331.556 .46 (043.3)

Vyshyvanyuk M. M. (2012.) Socio-economic development of small cities of the region: problems, tendencies, directions of regulation. Institute for Regional Studies of the National Academy of Sciences of Ukraine (Lviv). 252 p.

Yakovenko R.V., Kozenko R.O. (2010). Problems and prospects of human capital development. News of the KNTU. Economic sciences, Vol. 17. 447-451

Yarotskiy V.I. (2011). Economic-statistical research of labor resources of Ukraine. Theory and Practice of Public Administration.Vol. 4 (35). 1-8

Yatsyshyn Y.S.(2013). Socio-economic development of a large city in the context of globalization challenges: author's abstract. 08.00.05-Dissertation for obtaining the scientific degree of the candidate of economic sciences. Cherkasy state technological university (Cherkasy). $20 \mathrm{p}$. 
Zavadovska, Y. Y. (2016). Efficiency management in territorial projects of support to forced migrants. Scientific Messenger of the LNUVM BT. Series: economic sciences, vol. 4, 183-188.

Zavadovska, Y. Y. and Filyak, M. S. (2016). Migration flows of population during the crisis: the impact on social and economic development in the regions of Ukraine. Spolom(Lviv). 